\title{
The comparisons of fattening performance of Angus, Brangus and Hereford Bullocks at different initial body weight
}

\begin{abstract}
The aim of this experiment was to evaluate the fattening performance of growing beef cattle differing in initial body weight and breeds. The experiment was carried out with 314 imported 8-12 months old growing Hereford, Angus and Brangus bulls. They were allocated to three initial body weight groups (low:242; medium:280 and high:323kg). Fattening diet was formulated with $24.10 \%$ roughages (alfalfa and wheat straw) containing $14.0 \%$ crude protein. After two week adaptation period with 8 step diets $(100,83,75,67,54,43,33$, $24 \%$ roughage) were used. The fattening period of all groups was lasted 124 days. Breeds affected daily gain, final body weight and feed to gain ratio significantly $(\mathrm{P}<0.01)$. Angus $\left(1.5 \mathrm{~kg} \mathrm{~d}^{-1}\right)$ and Hereford $\left.1.51 \mathrm{~kg} \mathrm{~d}^{-1}\right)$ had higher daily gain than Brangus $\left(1.41 \mathrm{~kg} \mathrm{~d}^{-1}\right)$. Similar trends were obtained for final body weight and feed to gain ratio as well. Initial and final body weight was different significantly as expected $(\mathrm{P}<0.01)$. Daily gain were not affected by initial body weight although the daily gain tended to be higher in high initial body weight group (Low: $1.46 \mathrm{~kg} \mathrm{~d}^{-1}$; Medium: $1.45 \mathrm{~kg} \mathrm{~d}^{-1}$ and high $1.51 \mathrm{~kg} \mathrm{~d}^{-1}, \mathrm{P}>0.05$ ). Dry matter intake was in accordance in size group (Low: $8.35 \mathrm{~kg} \mathrm{~d}^{-1}$, Medium: $8.94 \mathrm{~kg} \mathrm{~d}^{-1}$ and High: $9.02 \mathrm{~kg} \mathrm{~d}^{-1}$ ). The growing cattle having medium initial body weight worsened feed to gain ration due to relatively high feed intake and lower daily gain compared to other initial body weight groups. Any parameter investigated was not affected by breed and initial body weight interaction $(\mathrm{P}>0.05)$.
\end{abstract}

Breeds affected daily gain, final body weight and feed to gain ratio significantly $(\mathrm{P}<0.01)$. Angus $\left(1.5 \mathrm{~kg} \mathrm{~d}^{-1}\right)$ and Hereford $\left.1.51 \mathrm{~kg} \mathrm{~d}^{-1}\right)$ had higher daily gain than Brangus $\left(1.41 \mathrm{~kg} \mathrm{~d}^{-1}\right)$. Higher daily gain in Angus and Hereford compared to Brangus in the present study may be related to frame size and/or maturity of the breeds. Angus is early maturing, Hereford is medium maturing and Brangus is late maturing relatively. Furthermore the study revealed that size of growing animal having higher than $300 \mathrm{~kg}$ may be fattened more efficiently (higher daily gain) as they have enough feed intake capacity and frame compared to lower body weight groups.

Keywords: initial body weight, angus, hereford, brangus, fattening performance, feed to gain, daily gain
Volume 5 Issue 4 - 2020

\author{
Serap Göncü,' Özgül Anitaș,' Murat \\ Görgülü² \\ 'Department of Animal Science, Cukurova University, Turkey \\ ${ }^{2}$ Ruminant Nutrition, Makrovit Animal Nutrition Technologies \\ Company, Turkey
}

Correspondence: Serap Göncü, Department of Animal Science, Çukurova University, Turkey, Tel +905333606282, Email seraponcu66@gmail.com

Received: July 13, 2020 | Published: August 31, 2020

\section{Introduction}

Cattle breeding have an important role in the livestock sector and contribute greatly to the animal production. Today, feedlot cattle farms changed production style to more complicated models using new crossbreed types to more profitable production. Today's conditions show that animal products required for human nutrition should be produced where they are consumed and economically. Turkey meat production in 2019 is 1 million 118 thousand 695 tons, of which $87.3 \%$, of beef $10.1 \%$ of the sheep, goat meat constitutes $2.5 \%$ (TUIK, 2020). However, red meat, which is of great importance in human nutrition, is not produced at a sufficient level. A healthy diet requires that people consume nutrients (water, carbohydrates, fat, protein, vitamins and mineral substances) adequate and balanced level. One person should consume 1 gram of protein per $\mathrm{kg}$ of body weight and $50-60 \%$ of these amount should be of animal origin for healthy life. Animal material that will provide the red meat needed by the country's population is brought from abroad.

Turkey has recently imported beef cattle such as Angus, Brangus, Hereford, Nelero, Limousin, Charrolais with 12 months old having from 80 to $350 \mathrm{~kg}$ weight range as a rule of Turkish Ministry of Agriculture and Forestry technical specifications for imported fattening animals. ${ }^{1}$ As a function of the age, body weight is most important factor for efficient and profitable cattle fattening systems. Young animal have better feed conversion rate because of their high protein deposition during fattening operation (Ensminger, 1968). At the end of the fattening of the preference of the animals with lower initial body weight in fattening operations provide more profitable results. ${ }^{2,3}$ Chewning et al. ${ }^{4}$ report that young animal show better growth performance than older animals. As reported above initial body weight or age may affect fattening performance and economy and carcass quality and thus it is important to test fattening performance of the imported fattening cattle having different size under Turkish feedlot and environmental conditions. Therefore, this study, aimed to determine optimum initial body weight of Angus, Brangus and Hereford under intensive fattening and in subtropical conditions.

\section{Material \& methods}

This study was conducted with Angus, Hereford, Brangus 8-12 months old age differing in initial body weights (low:242; medium:280 and high: $323 \mathrm{~kg}$ ). The experiment was carried out a Şanal Agricultural Enterprises intensive fattening farm is located 30 $\mathrm{km}$ from Adana which is located between 35-38 latitude and 34-46 
eastern longitude and in Mediterranean Region with a total 314 head growing cattle. The farm had 9 pen sized $18 \times 12 \mathrm{~m}$ were used to test fattening performance of growing cattle. Each pen had $18 \mathrm{~m}$ feeding space. The intensive fattening farm has a capacity of 400 heads and is designed free semi-open barn. Fattening diet was formulated with $24.10 \%$ roughages (alfalfa and wheat straw) containing $14.0 \%$ crude proteins. After two week adaptation period with 8 step diets $(100$ $83,75,67,54,43,33,24 \%$ roughage) by two days step up period, fattening period was lasted 124 days. Feed and water supplied ad libitum and feed intake was determined in group basis.

The total mixed ration (TMR) was formulated to get $1700 \mathrm{~g} /$ day (NRC 2016) with barley, corn flake, concentrate, wheat straw and alfalfa hay (Table 1). The same TMR was offered three times a day at 06:00, 14:00 and 22:00 according to animal number and size in each pen ad libitum for all fattening groups.

Table I The total mixed ration used in this study

\begin{tabular}{ll}
\hline Feeds & \%DM \\
\hline Barley & 29,49 \\
Corn Flake & 26,53 \\
Concentrate** & 19,88 \\
Alfalfa & 19,07 \\
Wheat Straw & 5,03 \\
Total & 100 \\
Nutrient compositions & \\
Dry matter (\% As fed)* & 66,13 \\
Roughage (\% DM) & 24,10 \\
Crude protein (\% DM) & 14,00 \\
Fat(\%DM) & 3,01 \\
Ash(\%DM) & 6,21 \\
NDF(\%DM) & 26,49 \\
\hline
\end{tabular}

*TMR dry matter content adjusted by adding water to mixer wagon

**concentrate contains $4 \%$ limestone, $4 \%$ sodium bicarbonate and $2 \%$ magnesium oxide, $1 \%$ salt and $0.3 \%$ vitamin mineral premix

Feed intake was determined in pen based and feed to gain ratio was calculated from pen average dry matter intake and individual daily gains. In order to meet the salt needs of bulls, salt blocks were supplied in the feeders continuously.

Daily gain was determined with 4 week period by weighing all animal before morning feeding. Feed analysis was determined according to methods described in AOAC. ${ }^{5}$ Body weight, daily gains and feed to gain ratio were analyzed by using the SPSS statistical package program. ${ }^{6}$ Study was carried out in a completely randomized design in a $2 \times 2$ factorial arrangement with three breeds and three initial body weight groups.

\section{Results and discussion}

In this study, it was aimed to compare the fattening performances of Angus, Hereford and Brangus breeds with different initial body weight groups. The fattening performances of Angus, Hereford and Brangus breeds were presented in Table 2 in detail according to breeds and initial body weight groups (main effects).

Daily gain were affected by initial body weight and high initial body weigh groups had higher daily gain than medium and low initial body weight groups ((Low: $1.46 \mathrm{~kg} \mathrm{~d}^{-1}$ and Medium: $1.45 \mathrm{~kg} \mathrm{~d}^{-1}$ vs. high $\left.1.51 \mathrm{~kg} \mathrm{~d}^{-1}, \mathrm{P}<0.01\right)$. Dry matter intake was in accordance in size group (Low: $8.35 \mathrm{~kg} \mathrm{~d}^{-1}$, Medium: $8.94 \mathrm{~kg} \mathrm{~d}^{-1}$ and High: $9.02 \mathrm{~kg} \mathrm{~d}^{-1}$ ). The medium initial body weight groups had higher feed to gain ration due to relatively high feed intake and lower daily gain compared to higher initial body weight groups. Breeds also affected daily gain and Angus and Hereford gained better than Brangus (Angus: $1.50 \mathrm{~kg} \mathrm{~d}^{-1}$ and Herefod: $1.51 \mathrm{~kg} \mathrm{~d}^{-1}$ vs. Brangus: $1.41 \mathrm{~kg} \mathrm{~d}^{-1}, \mathrm{P}<0.05$.)

Interestingly, any parameter investigated was not affected by interaction ( $P>0.05$, Table 3$)$. This result revealed that the live weight groups of each breed perform similarly.

The daily gains were reported for Hereford as $722 \mathrm{~g}^{7}$ and $1910 \mathrm{~g}^{8}$ for Angus $1160 \mathrm{~g}^{9}$ and $1660 \mathrm{~g}^{10}$ and for Brangus $643 \mathrm{~g}$ Özbeyaz ${ }^{11}$ and 980g. ${ }^{12}$ However, the performances of beef breeds in literature are not in agreement as reported..$^{7,11,13-19}$ In this study, the daily gains for Angus and Hereford were higher than the results of Chambaz et al. ${ }^{16}$; Duru and Sak, ${ }^{20}$; Hallo et al. ${ }^{21}$; Zengin ${ }^{9}$; Kayar and İnal, ${ }^{22}$; Barton et al., ${ }^{23}$ while similar to Schoeaman ${ }^{14}$; Cuvelier et al. ${ }^{10}$; Thomas et al., ${ }^{24}$; Göncü et al ${ }^{25}$ results. Also the daily gain values for Hereford were higher than the results of Duru and Sak, ${ }^{20}$; Muizniece and Kairisa ${ }^{7}$; Barton et al., ${ }^{23}$; similar to Kayar and İnal. ${ }^{22}$ The daily gain values for Brangus were higher than the results of Özbeyaz et al, ${ }^{11}$; Voisinet et al. ${ }^{12}$ These differences may be related to dietary regime, age, body weight, length of fattening and environmental conditions.

Table 2 The fattening performance of the Angus, Hereford and Brangus and initial body weight groups

\begin{tabular}{|c|c|c|c|c|c|c|c|}
\hline & \multirow{2}{*}{ Items } & \multirow{2}{*}{ No } & \multirow{2}{*}{$\begin{array}{l}\text { *IBW, } \\
\text { (kg) }\end{array}$} & \multirow{2}{*}{$\begin{array}{l}\text { FBW, } \\
\text { (kg) }\end{array}$} & \multirow{2}{*}{$\begin{array}{l}F I, \\
\left(k^{-1} d^{-1}\right)\end{array}$} & \multirow{2}{*}{$\begin{array}{l}\text { DG, } \\
\left(\mathrm{kg} \mathrm{d}^{-1}\right)\end{array}$} & \multirow{2}{*}{ FG } \\
\hline & & & & & & & \\
\hline & Angus & 84 & $282,0 \mathrm{I} \pm 2,04$ & $467,73 \pm 3,93 a$ & 8,54 & $1,50 \pm 0,03 a$ & $5,90 \pm 0,15 b$ \\
\hline \multirow[t]{2}{*}{ Breeds } & Brangus & 110 & $280,40 \pm 1,59$ & $455,50 \pm 3,27 b$ & 8,98 & $\mathrm{I}, 4 \mathrm{I} \pm 0,02 \mathrm{~b}$ & $6,64 \pm 0,13 a$ \\
\hline & Hereford & 120 & $282,65 \pm 1,49$ & $469,96 \pm 3,07 a$ & 8,79 & $I, 5 I \pm 0,02 a$ & $5,98 \pm 0,13 b$ \\
\hline \multirow[t]{2}{*}{ Significance } & $\mathrm{P}<$ & & 0,57 & 0,00 & & 0,00 & 0,00 \\
\hline & Low & 110 & $242,31 \pm 1,58 c$ & $423,58 \pm 3,26 c$ & 8,35 & $\mathrm{I}, 46 \pm 0,02 \mathrm{~b}$ & $5,89 \pm 0,13 b$ \\
\hline \multirow[t]{2}{*}{ Initial body weight } & Medium & 108 & $280,24 \pm I, 60 b$ & $459,58 \pm 3,29 b$ & 8,94 & $\mathrm{I}, 45 \pm 0,02 \mathrm{~b}$ & $6,47 \pm 0,14 a$ \\
\hline & High & 96 & $322,5 I \pm I, 68 a$ & $510,02 \pm 3,48 a$ & 9,02 & $I, 5 I \pm 0,03 a$ & $6,|3 \pm 0| 4 b$, \\
\hline Significance & $\mathrm{P}<$ & & 0,00 & 0,00 & & 0,01 & 0,00 \\
\hline
\end{tabular}

IBW, initial weight; FBW, final weight; Fl, feed intake; DG, daily gain; FG, feed to gain ratio

The differences between the means of groups carrying various letters in the same column are significant $(P<0.05)$ 
Table 3 Breeds and initial body weight interactions effects on fattening performance

\begin{tabular}{|c|c|c|c|c|c|c|c|}
\hline Breeds (B) & $\mathbf{N}$ & No & IBW, Kg & FBW,Kg & $\mathrm{FI}, \mathrm{kg} \mathrm{d}^{-1}$ & DG, $\mathbf{~ g ~ d ~ d ~}^{-1}$ & FG \\
\hline \multirow{4}{*}{ Angus } & Low & 28 & $244,39 \pm 3,53$ & $429,43 \pm 6,35$ & 8,15 & $\mathrm{I}, 49 \pm 0,05$ & $5,6 I \pm 0,26$ \\
\hline & Medium & 27 & $277, I I \pm 3,60$ & $463, I I \pm 6,47$ & 8,68 & $\mathrm{I}, 50 \pm 0,05$ & $6,08 \pm 0,26$ \\
\hline & High & 29 & $324,52 \pm 3,47$ & $510,66 \pm 6,24$ & 8,8 & $\mathrm{I}, 50 \pm 0,05$ & $5,96 \pm 0,26$ \\
\hline & Low & 42 & $242,07 \pm 2,5$ I & $420,17 \pm 5,18$ & 8,67 & $\mathrm{I}, 44 \pm 0,04$ & $6,27 \pm 0,21$ \\
\hline \multirow{3}{*}{ Brangus } & Medium & 41 & $281,73 \pm 2,92$ & $447,5 I \pm 5,25$ & 9,12 & $\mathrm{I}, 34 \pm 0,04$ & $7,18 \pm 0,21$ \\
\hline & High & 27 & $3|7,4| \pm 3,60$ & $498,82 \pm 6,46$ & 9,15 & $\mathrm{I}, 46 \pm 0,05$ & $6,41 \pm 0,21$ \\
\hline & Low & 40 & $240,48 \pm 2,58$ & $\begin{array}{l}421,15 \\
5,31\end{array}$ & 8,24 & $1,46 \pm 0,04$ & $5,79 \pm 0,22$ \\
\hline \multirow{2}{*}{ Hereford } & Medium & 40 & $28 I, 88 \pm 2,58$ & $468,|3 \pm 5,3|$ & 9,02 & $\mathrm{I}, 50 \pm 0,04$ & $6,15 \pm 0,22$ \\
\hline & High & 40 & $325,60 \pm 2,58$ & $520,60 \pm 5,31$ & 9,10 & $1,57 \pm 0,04$ & $6,0 \mathrm{I} \pm 0,22$ \\
\hline Significance & Int.(BxIBW) & & 0,17 & 0,25 & 0,18 & 0,26 & 0,54 \\
\hline
\end{tabular}

B, breeds; IBW, initial body weight; FBW, finaș body weight; FI, feed intake; FG, feed to gain ratio

Higher daily gain in Angus and Hereford compared to Brangus in the present study may be related to frame size and/or maturity of the breeds. Angus is early maturing, Hereford is medium maturing and Brangus is late maturing relatively. ${ }^{19}$ Furthermore some studies revealed that Voisinet et al. ${ }^{12}$ reported that Angus (early maturing) had higher daily gain ( 0.98 vs. $\left.1.24 \mathrm{~kg} \mathrm{~d}^{-1}\right)$ than Brangus (late maturing). Thus late maturing animal may gain less especially in earlier ages such as in our cases.

Higher daily gain for high initial body weight may be attributed to the high feed intake capacity and high frame allowing high feed intake and fleshing ability. Similarly Demircan ${ }^{26}$ evaluated the effect of initial body weight (181 kg, $256 \mathrm{~kg}$ and $329 \mathrm{~kg}$ ) and revealed that feed intake and daily gain were higher for the heavy initial body weight groups than others. Initial body weight is one of the main determinants of feed intake of growing cattle as reported NRC. ${ }^{27} \mathrm{NRC}^{27}$ equation as follows:

\section{DMI $(\mathrm{Kg} / \mathrm{day})=3.83+0.0143$ ISBW for steers}

DMI $(\mathrm{kg} /$ day $)=3.184+0.01536 \mathrm{x}$ ISBW for heifers

Where DMI is dry matter intake and ISBW is initial shrunk body weights.

However Arıkan and Gokhan ${ }^{28}$ reported that Limousin having light initial body weights ( 249 and $272 \mathrm{~kg}$ ) gained better than those having high initial body weight $(297 \mathrm{~kg})$. As discussed before, breeds, diet, days on feed, environment and housing condition may affect the results obtained. ${ }^{29,30}$

\section{Conclusion}

The results revealed that the growing Hereford and Angus bulls had higher daily gain than Brangus when the young animal (initial body weight range: $198-380 \mathrm{~kg}$ ) were used and fattened in a short period (124 days). Higher daily gain in Angus and Hereford compared to Brangus in the present study may be related to frame size and/or maturity of the breeds. Furthermore study revealed that growing animal having higher than $300 \mathrm{~kg}$ may be fattened more efficiently (higher daily gain) as they have enough feed intake capacity and more bonny (high frame) compared to lower body weight groups.

\section{Acknowledgments}

None.

\section{Funding}

None.

\section{Conflicts of interest}

The authors declare there are no conflicts of interest.

\section{References}

1. Haygem. Imported fattening cattle technical specifications. 2020.

2. İmik H, Günlü A, Tekerli M, et al. Economic analysis of cattle breeding in Afyon province and measures to be taken for a profitable fattening. Lalahan Hay Araşt Enst Derg. 2000;40(2):1-15.

3. Cevger Y, Güler H, Sarı̈zkan S, et al. The effect of initial live weight on technical and economic performance in cattle fattening. Turk $J$ Vet Anim Sci. 2003;27(5):1167-171

4. Chewning JJ, Brown AH, Johnson ZB, et al. Breed means for average daily gain, feed conversion and intake of beef bulls during postweaning feedlot performance tests. J Anim Sci. 1990;68(6):1500-1504.

5. AOAC. Official methods of analysis. 16th edn, Washington DC; 1998.

6. SPSS. SPSS for windows Release 21.0. SPSS Inc., Chicago IL. 2019

7. Muizniece I, Kairisa D. Fattening and slaughter results analysis of hereford breed bulls born in different seasons. 2018

8. McDonald MA, Slen SB, Hargrave HJ. Comparison of feedlot performance and carcass characteristics of charbray $\mathrm{X}$ hereford with hereford steers. Canadian Journal Of Animal Science. 1959.

9. Zengin A. Some performance values of Angus cattle raised in a private cattle farm in Denizli. Department of Animal Science, Institute of Science, Süleyman Demirel University; 2016.

10. Cuvelier C, Cabaraux JF, Dufrasne I, et al. Performance, slaughter characteristics and meat quality of young bulls from Belgian Blue, Limousin and Aberdeen Angus breeds fattened with a sugar-beet pulp or a cereal-based diet. Animal Science. 2006;82(1):125-132. 
11. Özbeyaz C, Yağcı T, Bağcı C, et al. Obtaining Brangus, Limozin and Simental bulls and Jersey cows for meat production using crossbreeds I. Growth. Büyüme. Lalahan Hay Araflt Enst Derg. 1997;37(1):1-19.

12. Voisinet BD, Grandin T, Tatum JD, et al. Feedlot cattle with calm temperaments have higher average daily gains than cattle. J ANIM SCI. 1997;75:892-896.

13. Pruksasri P, Preabprom S, Jetnasen C, et al. Fattening of American Brahman crossbred by small farmers. Department of Animal Science, Kasetsart University; 1990. 18 p.

14. Schoeaman SJ. Characterization of beef cattle breeds by virtue of their performances in the National beef cattle performance and progeny testing scheme. South African Journal of Animal Science. 1996;26(1):15-19.

15. Norris D, Macala J, Makore J, Feedlot performance of various breed groups of cattle fed low to high levels of roughage. Livestock Research for Rural Development. 2002.

16. Chambaz A, Scheeder MRL, Kreuzer M, et al. Meat quality of angus, simmental, charolais and limousin steers compared at the same intramuscular fat content. Meat Sci. 2003;63:491-500.

17. Muižniece I, Kairiša D. Different beef breed cattle fattening results analysis. Research for Rural Development. 2016.

18. Suksombat W, Meeprom C, Orkdaeng K, et al. Performance, carcass quality and fatty acid profile of crossbred brahman beef steers receiving palm or rice bran oil. Songklanakarin J Sci Technol. 2018;40(1):197-203.

19. Phillips CJC. Principles of cattle production. 3rd edn. Wallingford CABI, Wallingford Oxon, UK; 2018.

20. Duru S, Sak H. Beside the Turkey received simmental, aberdeen angus, hereford, limousin and charolais breed of cattle fattening performance and carcass characteristics. Türk Tarım Gıda Bilim ve Teknoloji Dergisi. 2017;5(11):1383-1388.
21. Holló G, Nuernberg K, Somogyi T, et al. Comparison of fattening performance and slaughter value of local Hungarian cattle breeds to international breeds. Archiv Tierzucht. 2012;55(1):1-12.

22. Kayar $\mathrm{T}$, İnal Ş. Comparison of fattening performance of Limousine, Charolais, Angus and Hereford breed bulls. Eurasian J Vet Sci. 2019;35(2):104-108.

23. Barton L, Rehak D, Teslik V, et al. Effect of breed on growth performance and carcass composition of Aberdeen Angus, Charolais, Hereford and Simmental bulls. Czech Journal of Animal Science. 2006;51(2):47-53.

24. Thomas MG, Enns RM, Hallford DM, et al. Relationships of metabolic hormones and serum glucose to growth and reproductive development in performance-tested Angus, Brangus, and Brahman bulls. J ANIM SCI. 2002;80:757-767.

25. Göncü S, Bozkurt S, Görgülü M. The effect of yeast (Saccharomyces cerevisiae) on fattening performances of growing cattle. MOJ Eco Environ Sci. 2020;5(3):109-111.

26. Demircan V. The effect of initial fattening weight on sustainability of beef cattle production in feedlots. Spanish Journal of Agricultural Research. 2008;6:17-24.

27. NRC. Nutrient requirements of dairy cattle. National Research Council, Washington DC; 2016.

28. Arıkan MS, ve Gökhan EE. The economic effect of live weight at the beginning of fattening on fattening performance in limousine breeds. Eurasian J Vet Sci. 2018;34(4):228-232.

29. Göncü S, Bozkurt S, Sucak M. Turkey fattened bulls head of imported hybrid mixed effect on fattening performance of body weight. Uluslararast Doğu Akdeniz Tarımsal Araştırma Enstitüsü Dergisi. 2019;2(2):63-72.

30. Thornton JH, Owens FN, Gill DR. Feed intake by feedlot beef steers influence of initial weight and time on feed. Okl Agri Exp Stn Res Rep. 1985:320-331. 